\title{
Online Learning in Egyptian Universities Post COVID-19 Pandemic: A Student's Perspective
}

\author{
https://doi.org/10.3991/ijet.v16i18.25135 \\ Hebatalla Kaoud( ${ }^{\bowtie}$, Dina El-Shihy, Mostafa Yousri \\ NewGiza University (NGU), Cairo, Egypt \\ Heba.kaoud@ngu.edu.eg
}

\begin{abstract}
The COVID-19 Pandemic has challenged the educational systems worldwide, and in an attempt to overcome such challenges, educational institutions were forced to adjust their educational content from the traditional methods of learning to online methods of delivery instead. This paper is the first paper to collect data from three different types of universities to examine the students' attitudes towards online learning in Egypt amid COVID-19. A total of 450 undergraduate students were surveyed to predict online learning achievement. The study examined issues related to technical challenges, electronic communication, online learning motivation, students' personal attributes and competencies, and their interactions with colleagues and instructors. The findings of the study provide useful insights regarding the students' attitudes towards currently adopted methods of online learning and suggest several implications that could aid educational institutions in the formulation of strategies that would enhance the overall online learning experience. This paper also serves as a foundation for further research and discussion.
\end{abstract}

Keywords-Attitudes, Challenges, Online learning, Motivation, Undergraduate Students

\section{Introduction}

According to Cucinotta, D., and Vanelli, M [1], the World Health Organization (WHO) announced COVID-19 as a global public health emergency of international concern on 30th January 2020 and a pandemic on 11th March 2020.

This health crisis has had a serious impact on schools, teachers and educational establishments around the world [2,3]. The pandemic compelled schools, colleges and universities to shut down their campuses so that students could follow the social distancing policies [4], and has prompted academic experts to take distant learning as a viable choice instead of the traditional methods of face-to-face learning [5].

\subsection{The Transition from Traditional to Online Learning}

Online learning shifts education from a conventional traditional classroom that is teacher-centered, to a student-centered one; where students are more responsible for 
their learning [6,7]. The sudden transition to online learning has become a measure of organizational resilience, where most academic institutions merely concentrated on moving the educational content to the digital world rather than focusing on the online teaching and delivery methods [8].

Distance education is a versatile and mobile category that has evolved for nearly two decades and has become mainstream as a result of the COVID-19 pandemic in 2020 [9].

\subsection{The Challenges of Online Learning}

The rapid transition towards online learning is connected to numerous obstacles and challenges $[10,11]$. But since no one knows when this pandemic will end entirely, educational institutions around the world have chosen to use the digital tools currently available to build online learning materials for students from all academic fields [5].

Basilaia and Kvavadze [12] proposed that online learning can be competitive and effective in technologically advanced nations. However, according to Zhong [13], the scarcity of funding in academic institutions have hindered organizational responsiveness and students' ability to engage in digital learning, due to the inadequate internet coverage and usability, as well as the lack of advanced technologies.

It would be possible for distance educators to enhance their teaching skills and styles by focusing on the difficulties and challenges encountered by students [14, 15], especially in the era of Covid-19 that mandated the use of online learning and blended learning by universities [16]. Afterwards, universities have shifted from an entirely online system to blended learning, which has then become an accepted system in higher education $[17,18]$. However, the major concern of undergoing this system relates to how to sustain positive attitudes towards online learning [19].

Studies have revealed that there are four important forms of online interactions; student-content, student-interface, student-teacher, and peer interactions [20], [21], [22]. Several different problems were identified by the advanced education understudies that include the lack of proper communication with instructors, response time and the absence of traditional classroom socialization [23]. Britt [24] stated that in online learning, students only interact with their fellow students electronically and seldom see their fellow students in person, and so the real-time sharing of feelings, expertise and information becomes partially absent.

There is a correlation between students' learning motivation and attitudes during online learning, and such factors affect their ability to take online classes or use online learning platforms $[25,26]$. The instructor must make the idea of studying as enticing as possible, in order to sustain the students' motivation and avoid boredom [23], especially since students must adapt rapidly to the online methods of learning [27].

In online classes, instructors should use various means, such as animation, visualization, video, audio, and documents, to enhance students' engagement [28, 29]. Moreover, technological devices, program design, choice of instructors, interactive curriculums, and supportive stakeholders are required for an effective delivery of content [30]. 


\subsection{Objectives}

Bernard et al. [31] highlighted the need to explore the challenges faced in online learning by higher education students, and even though a number of studies have proven that students can learn online just as well as they do face-to-face, Nora and Synder [32] and Patterson and McFadden [33] argued that students tend to drop at higher rates in online courses.

During the Covid-19 pandemic lockdown, it was found that about 78 percent of students prefer classroom learning over online learning, which makes it necessary to implement all aspects of online learning [34].

Adnan and Anwar [2] stated that the challenges and opportunities associated with elearning during pandemics have been addressed in some recent studies. However, according to Almanthari, et al. [3], since students' input is significant, future studies should further investigate their attitudes and examine the opportunities and challenges that they face in online learning.

More study is required to explore the complexities that discourage students from achieving their learning objectives in the online learning environment [2]. Moreover, Alasmari [35] \& Basilaia and Kvavadze [12] proposed that future research should examine the effectiveness of online learning.

Obeidat [36] also suggests that there is a need for more studies on online learning in the Middle East. In addition to that, according to a study conducted by Ghenghesh et al. [37] on the Faculty of Informatics and Computer Science in a private university in Egypt prior to COVID-19, there is a need to explore the impact of e-learning in more faculties and universities in Egypt.

In the light of this gap, the present study aims to explore the attitudes and challenges faced by students in the online learning environment amid COVID-19 pandemic. The study focuses on undergraduate students from the schools of business in three different universities in Egypt.

\section{Methodology}

This study employed a survey that was originally developed by Bernard, et al. [31], and validated by Tamim, et al. [38]. Prior to the questionnaire distribution, the researchers conducted a pilot study on students from three universities. Necessary modifications were made according to their responses, feedback, comments and suggestions. In addition to the elimination of some statements that were out of the scope of this study. Finally, a 24 items survey was used to analyze the attitudes of undergraduate students in Egypt regarding online learning.

The sample chosen was from the Schools of Business from three different universities in Egypt: (1) a Private University (PR), (2) a National/ non-profit University (NA), and (3) a Public University (PU). Students selected were enrolled in their second, third, or fourth year.

The Data were collected online using "Survey Monkey" in December 2020. The survey responses with missing data or survey responses that had the same rating for all survey statements (e.g., all "neutral") were disregarded and judged to have not been 
mindfully completed. After filtering the data, a total sample of 450 valid surveys remained; 150 from each university.

The data were analyzed using frequencies and percentages of the students' responses.

\section{Results and Discussion}

Table 1. Survey Results

\begin{tabular}{|c|c|c|c|c|c|}
\hline Question & Answer & $\%$ PR & $\% \mathrm{PU}$ & $\% \mathbf{N A}$ & $\%$ Total \\
\hline \multicolumn{6}{|l|}{ Technicalities } \\
\hline \multirow{3}{*}{$\begin{array}{l}\text { I am able to easily access the Internet as } \\
\text { needed for my studies }\end{array}$} & Agree & $76.67 \%$ & $38.67 \%$ & $66.67 \%$ & $60.67 \%$ \\
\hline & Neutral & $16.00 \%$ & $29.33 \%$ & $22.00 \%$ & $22.44 \%$ \\
\hline & Disagree & $7.33 \%$ & $32.00 \%$ & $11.33 \%$ & $16.89 \%$ \\
\hline \multirow{3}{*}{$\begin{array}{l}\text { Learning is the same in class and at home on } \\
\text { the Internet }\end{array}$} & Agree & $21.33 \%$ & $22.00 \%$ & $25.33 \%$ & $22.89 \%$ \\
\hline & Neutral & $11.33 \%$ & $12.67 \%$ & $16.67 \%$ & $13.56 \%$ \\
\hline & Disagree & $67.33 \%$ & $65.33 \%$ & $58.00 \%$ & $63.56 \%$ \\
\hline \multirow{3}{*}{$\begin{array}{l}\text { I believe a complete course can be given by the } \\
\text { Internet without difficulty }\end{array}$} & Agree & $26.00 \%$ & $15.33 \%$ & $27.33 \%$ & $22.89 \%$ \\
\hline & Neutral & $18.00 \%$ & $17.33 \%$ & $10.00 \%$ & $15.11 \%$ \\
\hline & Disagree & $56.00 \%$ & $67.33 \%$ & $62.67 \%$ & $62.00 \%$ \\
\hline \multicolumn{6}{|l|}{ Electronic Communication } \\
\hline \multirow{3}{*}{$\begin{array}{l}\text { I am comfortable communicating electroni- } \\
\text { cally }\end{array}$} & Agree & $44.67 \%$ & $38.67 \%$ & $46.67 \%$ & $43.33 \%$ \\
\hline & Neutral & $31.33 \%$ & $24.67 \%$ & $32.00 \%$ & $29.33 \%$ \\
\hline & Disagree & $24.00 \%$ & $36.67 \%$ & $21.33 \%$ & $27.33 \%$ \\
\hline \multirow{3}{*}{$\begin{array}{l}\text { I am willing to actively communicate with my } \\
\text { classmates and instructors electronically }\end{array}$} & Agree & $52.67 \%$ & $38.00 \%$ & $54.67 \%$ & $48.44 \%$ \\
\hline & Neutral & $27.33 \%$ & $20.67 \%$ & $30.00 \%$ & $26.00 \%$ \\
\hline & Disagree & $20.00 \%$ & $41.33 \%$ & $15.33 \%$ & $25.56 \%$ \\
\hline \multirow{3}{*}{ I am comfortable with written communication } & Agree & $70.67 \%$ & $47.33 \%$ & $52.67 \%$ & $56.89 \%$ \\
\hline & Neutral & $20.67 \%$ & $28.00 \%$ & $34.00 \%$ & $27.56 \%$ \\
\hline & Disagree & $8.67 \%$ & $24.67 \%$ & $13.33 \%$ & $15.56 \%$ \\
\hline \multirow{3}{*}{$\begin{array}{l}\text { I feel comfortable communicating online in } \\
\text { English }\end{array}$} & Agree & $83.33 \%$ & $42.67 \%$ & $62.67 \%$ & $62.89 \%$ \\
\hline & Neutral & $9.33 \%$ & $36.00 \%$ & $23.33 \%$ & $22.89 \%$ \\
\hline & Disagree & $7.33 \%$ & $21.33 \%$ & $14.00 \%$ & $14.22 \%$ \\
\hline \multirow{3}{*}{$\begin{array}{l}\text { I can practice English grammar during Internet } \\
\text { activities outside of class }\end{array}$} & Agree & $55.33 \%$ & $41.33 \%$ & $53.33 \%$ & $50.00 \%$ \\
\hline & Neutral & $29.33 \%$ & $30.67 \%$ & $32.00 \%$ & $30.67 \%$ \\
\hline & Disagree & $15.33 \%$ & $28.00 \%$ & $14.67 \%$ & $19.33 \%$ \\
\hline \multirow{3}{*}{$\begin{array}{l}\text { I possess sufficient computer keyboarding } \\
\text { skills for doing online work }\end{array}$} & Agree & $71.33 \%$ & $48.67 \%$ & $66.67 \%$ & $62.22 \%$ \\
\hline & Neutral & $20.67 \%$ & $33.33 \%$ & $28.00 \%$ & $27.33 \%$ \\
\hline & Disagree & $8.00 \%$ & $18.00 \%$ & $5.33 \%$ & $10.44 \%$ \\
\hline \multirow{3}{*}{$\begin{array}{l}\text { I feel comfortable composing text on a com- } \\
\text { puter in an online learning environment }\end{array}$} & Agree & $63.33 \%$ & $36.67 \%$ & $57.33 \%$ & $52.44 \%$ \\
\hline & Neutral & $27.33 \%$ & $28.00 \%$ & $30.67 \%$ & $28.67 \%$ \\
\hline & Disagree & $9.33 \%$ & $35.33 \%$ & $12.00 \%$ & $18.89 \%$ \\
\hline \multicolumn{6}{|l|}{ Online Learning Motivation } \\
\hline & Agree & $24.00 \%$ & $24.00 \%$ & $32.67 \%$ & $26.89 \%$ \\
\hline
\end{tabular}




\begin{tabular}{|c|c|c|c|c|c|}
\hline \multirow{2}{*}{$\begin{array}{l}\text { I believe that learning on the Internet outside } \\
\text { of class is more motivating than a regular } \\
\text { course }\end{array}$} & Neutral & $22.00 \%$ & $10.67 \%$ & $25.33 \%$ & $19.33 \%$ \\
\hline & Disagree & $54.00 \%$ & $65.33 \%$ & $42.00 \%$ & $53.78 \%$ \\
\hline \multirow{3}{*}{$\begin{array}{l}\text { I am motivated by the material in an Internet } \\
\text { activity outside of class }\end{array}$} & Agree & $49.33 \%$ & $36.67 \%$ & $43.33 \%$ & $43.11 \%$ \\
\hline & Neutral & $31.33 \%$ & $27.33 \%$ & $32.67 \%$ & $30.44 \%$ \\
\hline & Disagree & $19.33 \%$ & $36.00 \%$ & $24.00 \%$ & $26.44 \%$ \\
\hline \multirow{3}{*}{$\begin{array}{l}\text { I believe that material in an Internet course is } \\
\text { better prepared than a traditional class }\end{array}$} & Agree & $22.00 \%$ & $24.00 \%$ & $30.00 \%$ & $25.33 \%$ \\
\hline & Neutral & $34.00 \%$ & $22.00 \%$ & $34.67 \%$ & $30.22 \%$ \\
\hline & Disagree & $44.00 \%$ & $54.00 \%$ & $35.33 \%$ & $44.44 \%$ \\
\hline \multicolumn{6}{|l|}{ Personal Attributes and Competencies } \\
\hline \multirow{3}{*}{$\begin{array}{l}\text { When it comes to learning and studying, I am a } \\
\text { self-directed person }\end{array}$} & Agree & $70.00 \%$ & $56.00 \%$ & $54.00 \%$ & $60.00 \%$ \\
\hline & Neutral & $22.67 \%$ & $25.33 \%$ & $31.33 \%$ & $26.44 \%$ \\
\hline & Disagree & $7.33 \%$ & $18.67 \%$ & $14.67 \%$ & $13.56 \%$ \\
\hline \multirow{3}{*}{$\begin{array}{l}\text { In my studies, I am self-disciplined and find it } \\
\text { easy to set aside reading and homework time }\end{array}$} & Agree & $61.33 \%$ & $42.67 \%$ & $48.00 \%$ & $50.67 \%$ \\
\hline & Neutral & $28.00 \%$ & $38.67 \%$ & $38.67 \%$ & $35.11 \%$ \\
\hline & Disagree & $10.67 \%$ & $18.67 \%$ & $13.33 \%$ & $14.22 \%$ \\
\hline \multirow{3}{*}{$\begin{array}{l}\text { I am able to manage my study time effectively } \\
\text { and easily complete assignments on time }\end{array}$} & Agree & $64.00 \%$ & $50.00 \%$ & $53.33 \%$ & $55.78 \%$ \\
\hline & Neutral & $25.33 \%$ & $30.00 \%$ & $32.00 \%$ & $29.11 \%$ \\
\hline & Disagree & $10.67 \%$ & $20.00 \%$ & $14.67 \%$ & $15.11 \%$ \\
\hline \multirow{3}{*}{$\begin{array}{l}\text { In my studies, I set goals and have a high de- } \\
\text { gree of initiative }\end{array}$} & Agree & $70.67 \%$ & $64.00 \%$ & $59.33 \%$ & $64.67 \%$ \\
\hline & Neutral & $21.33 \%$ & $25.33 \%$ & $34.67 \%$ & $27.11 \%$ \\
\hline & Disagree & $8.00 \%$ & $10.67 \%$ & $6.00 \%$ & $8.22 \%$ \\
\hline \multirow{3}{*}{$\begin{array}{l}\text { I feel that my background and experience will } \\
\text { be beneficial to my studies }\end{array}$} & Agree & $74.67 \%$ & $39.33 \%$ & $49.33 \%$ & $54.44 \%$ \\
\hline & Neutral & $20.00 \%$ & $33.33 \%$ & $36.67 \%$ & $30.00 \%$ \\
\hline & Disagree & $5.33 \%$ & $27.33 \%$ & $14.00 \%$ & $15.56 \%$ \\
\hline \multicolumn{6}{|l|}{ Interactions with Colleagues and Instructors } \\
\hline \multirow{3}{*}{$\begin{array}{l}\text { As a student, I enjoy working with other stu- } \\
\text { dents in groups }\end{array}$} & Agree & $58.00 \%$ & $58.00 \%$ & $68.00 \%$ & $61.33 \%$ \\
\hline & Neutral & $21.33 \%$ & $23.33 \%$ & $19.33 \%$ & $21.33 \%$ \\
\hline & Disagree & $20.67 \%$ & $18.67 \%$ & $12.67 \%$ & $17.33 \%$ \\
\hline \multirow{3}{*}{$\begin{array}{l}\text { I can discuss with other students during Inter- } \\
\text { net activities outside of class }\end{array}$} & Agree & $52.00 \%$ & $37.33 \%$ & $48.67 \%$ & $46.00 \%$ \\
\hline & Neutral & $28.67 \%$ & $29.33 \%$ & $28.67 \%$ & $28.89 \%$ \\
\hline & Disagree & $19.33 \%$ & $33.33 \%$ & $22.67 \%$ & $25.11 \%$ \\
\hline \multirow{3}{*}{$\begin{array}{l}\text { I can work in a group during Internet activities } \\
\text { outside of class }\end{array}$} & Agree & $54.67 \%$ & $40.67 \%$ & $52.00 \%$ & $49.11 \%$ \\
\hline & Neutral & $27.33 \%$ & $22.67 \%$ & $31.33 \%$ & $27.11 \%$ \\
\hline & Disagree & $18.00 \%$ & $36.67 \%$ & $16.67 \%$ & $23.78 \%$ \\
\hline \multirow{3}{*}{$\begin{array}{l}\text { I can collaborate with other students during In- } \\
\text { ternet activities outside of class }\end{array}$} & Agree & $57.33 \%$ & $36.00 \%$ & $54.00 \%$ & $49.11 \%$ \\
\hline & Neutral & $28.67 \%$ & $32.00 \%$ & $33.33 \%$ & $31.33 \%$ \\
\hline & Disagree & $14.00 \%$ & $32.00 \%$ & $12.67 \%$ & $19.56 \%$ \\
\hline \multirow{3}{*}{$\begin{array}{l}\text { I feel that face-to-face contact with my instruc- } \\
\text { tor is necessary for learning to occur }\end{array}$} & Agree & $66.67 \%$ & $75.33 \%$ & $62.00 \%$ & $68.00 \%$ \\
\hline & Neutral & $25.33 \%$ & $14.67 \%$ & $26.67 \%$ & $22.22 \%$ \\
\hline & Disagree & $8.00 \%$ & $10.00 \%$ & $11.33 \%$ & $9.78 \%$ \\
\hline \multirow{3}{*}{$\begin{array}{l}\text { I could pass a course on the Internet without } \\
\text { any teacher assistance }\end{array}$} & Agree & $38.00 \%$ & $25.33 \%$ & $24.67 \%$ & $29.33 \%$ \\
\hline & Neutral & $22.67 \%$ & $22.67 \%$ & $23.33 \%$ & $22.89 \%$ \\
\hline & Disagree & $39.33 \%$ & $52.00 \%$ & $52.00 \%$ & $47.78 \%$ \\
\hline
\end{tabular}


The study results identified five main challenges faced by students in online learning: Technicalities, Electronic Communication, Online Learning Motivation, Personal Attributes and Competencies, and Interactions with Colleagues and Instructors.

\subsection{Technicalities}

As shown in Table 1, concerning ease of internet access, PR and NA students reported that they can easily access the internet as needed for their studies $(76.67 \%$ and $66.67 \%)$, however, PU students were divided between agree and disagree $(38.67 \% \%$ and $32 \%$ respectively), lowering the overall agree percentage to $60.67 \%$. This could be due to technical issues which are considered challenges to online learning and include difficulty of access to computers, power outages, and challenges related to internet connectivity [16], e.g., slow, unreliable, or no internet access [39].

As reported by Muhammad \& Srinivasan (2021) [40], The reliability of the internet connection is critical to the successful delivery of live lectures in an online context. If there is a loss of internet connection or inadequate connectivity during a lecture, the student will have an ineffective and, in some cases, unpleasant learning environment.

Moving to the comparison between traditional and online learning, a total of $63.56 \%$ believed that learning in class was not the same as learning at home on the internet; PR scored the highest, followed by PU, and then NA $(67.33 \%, 65.33 \%$, and 58\% respectively). Moreover, more than half the students $(62 \%)$ believed that they cannot complete an online course without difficulty, where PU scored the highest, followed by NA, and then PR $(67.33 \%, 62.67 \%$, and 56\% respectively). Reasons for that may lie in students' inability to adapt with modern technology since they have been used to the traditional methods of learning, which makes it a challenge for them to replace it with online learning [16]. In addition to that, the lack of students' experience with the online methods of learning makes it difficult for them to grapple with this learning trend [41].

\subsection{Electronic Communication}

Results revealed that only $43.33 \%$ felt comfortable communicating electronically $(\mathrm{NA}=46.67 \%, \mathrm{PR}=44.67 \%$, and $\mathrm{PU}=38.67 \%$ ), which was in support with Koi- Akrofi, et al. [16], who mentioned that online learning does not allow students the chance to work on their communication skills.

More than half of NA and PR students were willing to actively communicate with their classmates and instructors electronically (54.67\% and 52.67\% respectively), however, the higher percentage of PU students disagreed $(41.33 \% \%)$, which lowered the overall percentage of students who agreed to $48.44 \%$. Findings revealed that $56.89 \%$ of the respondents felt comfortable with written communication $(\mathrm{PR}=70.67 \%$, $\mathrm{NA}=52.67 \%$, and $\mathrm{PU}=47.33 \%$ ), 62.89\% felt comfortable communicating online in English $(\mathrm{PR}=83.33 \%, \mathrm{NA}=62.67 \%$, and $\mathrm{PU}=42.67 \%)$, half the respondents could practice English grammar during activities outside of class $(\mathrm{PR}=55.33 \%, \mathrm{NA}=53.33 \%$, and $\mathrm{PU}=41.33 \%$ ).

Regarding the computer keyboarding skills, $62.22 \%$ of the students possessed sufficient skills for doing their online work $(\mathrm{PR}=71.33 \%, \mathrm{NA}=66.67 \%$ and $\mathrm{PU}=48.67 \%)$. 
PR and NA students felt comfortable composing text on a computer during online learning (63.33\% and $57.33 \%$ respectively), however the PU students were divided between agree and disagree (36.67\% and $35.33 \%$ respectively), lowering the overall agree percentage to $52.44 \%$.

Challenges to online learning may influence the students' ability to effectively and actively engage in online learning, these obstacles could relate to the students' lack of academic skills, communication skills, language skills, English skills, writing skills, or typing skills needed for online learning [42], or may relate to shyness, expressions of self-doubt, uncertainty or fear concerning their studying approaches [43].

\subsection{Online Learning Motivation}

Results revealed that $53.78 \%$ of the respondents were less motivated with learning outside of class ( $\mathrm{PU}=65.33 \%, \mathrm{PR}=54 \%$, and $\mathrm{NA}=42 \%$ ). Students' motivation in learning can affect their online learning experience and persistence [44]. Moreover, learner motivation is one of the most severe challenges to online learning and has a strong relationship with the effectiveness of online learning [42].

Only $43.11 \%$ of students were motivated by the material in an internet activity $(\mathrm{PR}=49.33 \%, \mathrm{NA}=43.33 \%$, and $\mathrm{PU}=36.67 \%)$; noting that the percentages of PU students who agreed and disagreed were almost the same (36.67\% and 36\% respectively). Moreover, $44.44 \%$ of the respondents did not believe that material in online learning is better prepared than a traditional class ( $\mathrm{PU}=54 \%, \mathrm{PR}=44 \%$, and $\mathrm{NA}=35.33 \%$ ); noting that the percentages of NA students' respondents were almost equally distributed (agree $=30 \%$, neutral $=34.67 \%$, and disagree $=35.33 \%$ ). Those low percentages coincide with the findings of Muilenburg and Berge [42], Farrell and Brunton [43], Baticulon, et al. [39], and Koi- Akrofi, et al. [16] who found a strong association between the administrative instructor issues and the learner's motivation. Administrative issues occur when class size is not right for online learning [42], online courses are designed inappropriately [43], and poor quality of learning materials [39]. Koi- Akrofi, et al. [16] further elaborated on that explaining that content issues are considered one of the main challenges facing online learning and relate to two main dimensions: the lack of content and the lack of understanding the content.

According to the study of Basha et al (2021) [45] that was conducted to analyze the philosophy of distance learning in the Egyptian construction engineering education, most students preferred face-to-face and written communication with teaching assistants. Students may use tools such as recorded lectures and courses to become more involved with course content by studying at any time, any place, and at their own pace. This can assist them in managing their time, resulting in increased motivation and productivity, as well as more effective learning.

\subsection{Personal Attributes and Competencies}

Regarding learning and studying, $60 \%$ of the respondents reported that they are selfdirected ( $\mathrm{PR}=70 \%, \mathrm{PU}=56 \%$, and $\mathrm{NA}=54 \%$ ), and $50.67 \%$ are self-disciplined and find it easy to set aside reading and homework time $(\mathrm{PR}=61.33 \%, \mathrm{NA}=48 \%$, and $\mathrm{PU}=$ 
42.67\%), 55.78\% are able to manage their study time effectively and easily complete assignments on time $(\mathrm{PR}=64 \%, \mathrm{NA}=53.33 \%$, and $\mathrm{PU}=50 \%), 64.67 \%$ can set goals and have a high degree on initiative in their studies $(\mathrm{PR}=70.67 \%, \mathrm{PU}=64 \%$, and $\mathrm{NA}=$ $59.33 \%$ ). It is worth mentioning that PR students scored the highest on all the personal attributes and competencies in comparison to NA and PU, which might refer to their background and experience, since according to the findings of this study, $54.44 \%$ of the respondents felt that their background and experience are beneficial to their studies $(\mathrm{PR}=74.67 \%, \mathrm{NA}=49.33 \%$, and $\mathrm{PU}=39.33 \%)$.

According to Koi- Akrofi, et al. [16], students who are not self- regulated and selfdisciplined may face difficulties in online learning, since it is all dependent on them, unlike face-to-face learning, where instructors and colleagues serve as encouragers and helpers in the learning process. That was also in support with Zhu, et al. [44], who mentioned that students who have self-regulated learning skills are more likely to be engaged in online learning. Furthermore, Farrell and Brunton [43], added that students who have better time management skills tend to continue their online classes, since time management skills enable them to establish a successful study routine, structure and plan their studies effectively around their responsibilities.

\subsection{Interactions with Colleagues and Instructors}

Concerning the students' interactions with their colleagues, $61.33 \%$ enjoyed working with other students in groups ( $\mathrm{NA}=68 \%, \mathrm{PR}$ and $\mathrm{PU}=58 \%$ each). However, when it came to internet activities outside of class, only $46 \%$ reported that they can discuss with other students $(\mathrm{PR}=52 \%, \mathrm{NA}=48.67 \%$, and $\mathrm{PU}=37.33 \%)$, noting that PU students' responses to agree and disagree were very close $(37.33 \%$, and $33.33 \%$ respectively).

In addition to that, $49.11 \%$ can work in a group $(\mathrm{PR}=54.67 \%, \mathrm{NA}=52 \%$, and $\mathrm{PU}=$ $40.67 \%)$, again, PU students' responses to agree and disagree were very close $(40.67 \%$, and $36.67 \%$ respectively), and $49.11 \%$ can collaborate with other students (PR= $57.33 \%, \mathrm{NA}=54 \%$, and $\mathrm{PU}=36 \%$ ), it is worth mentioning that PU students' responses were almost equally distributed among agree, neutral and disagree $(36 \%, 32 \%$, and $32 \%$ respectively).

In other words, PR and NA students generally held positive attitudes regarding working with their colleagues in groups and were indifferent in terms of whether it was online or offline. That was supported by Farrell and Brunton [43], who argued that the role of peers is valued as a source of support and a part of the students online learning experience that are enhanced by the students' discussions, module discussion forums and students debate with their classmates. Moreover, the Board of Trustees of the University of Illinois [46] stated that online learning enhanced effective exchange of ideas and interaction among students and their peers, and Amir, et al. [47] found that most of the students believed that online learning was an effective method and helped them benefit from their peers.

However, with regards to PU students, they only responded favorably towards working with others in class and the percentages dropped dramatically when it came to online group interactions. The lack of classroom socialization is one of the main reasons 
for unsuccessful online learning [48], [36], [2], where students are not given the chance to properly interact with their peers in comparison to face-to-face learning [36]. That was further justified by Sit, et al. [49] who explained that students prefer meeting with their peers and group mates physically rather than using online communications and believed that on campus meetings were more valuable than online channels of communications, since they enhanced group discussions, clarified difficult issues related to learning, and enabled a sense of classroom community.

Online learning is the opposite of face-to-face learning and considerably removes the socialization element from it, which hampers the students' social development, constructive and healthy interactions and communication, especially when they are given a choice between online learning and face-to-face learning [16]. This was in support with Muilenburg and Berge [42], who mentioned that the lack of social interaction was one of the most important challenges in online learning, which included the lack of student collaboration online and their inability to interact with their peers. Students appreciate face-to-face education due to the degree of socialization regarded as opportunities for students to share and exchange ideas, as well as between students and professors. Students build their scientific and professional identities and, eventually, prepare themselves for the business world through this socialization [50].

Finally, with regards to the students' interactions with their instructors, $68 \%$ of the students felt that face-to-face contact with their instructor was necessary for learning to occur $(\mathrm{PU}=75.33 \%, \mathrm{PR}=66.67 \%$, and $\mathrm{NA}=62 \%)$, and $47.78 \%$ of the respondents could not pass a course on the internet without any teacher assistance (PU and NA= $52 \%$ each, and $\mathrm{PR}=39.33 \%$ ), noting that $\mathrm{PR}$ students' responses to agree and disagree were almost equal ( $38 \%$ and $39.33 \%$ respectively). Results were in support with Firmansyah, et al. [51], Liu [52], and Baticulon, et al. [39], who argued that poor communication between students and instructors, as well as the gaps in skills and knowledge in the teaching methods were considered challenges for students in online learning during COVID 19 pandemic.

Furthermore, Koi- Akrofi, et al. [16] added that online learning does not have immediate feedback and that instructors may not be readily able to offer input. Because instructors do not receive instant feedback, distance learning is considerably more difficult in this scenario. As a result, instructors cannot quickly change their teaching techniques [50]. According to Ohene and Essuman [15], instructors tolerate students input and provide more constructive feedback in classrooms and traditional methods of learning in comparison to online learning, which lacks some of these forms of interaction.

\section{Implications}

This study emphasized that the challenges to online learning from the students' perspective are interrelated. In the light of the findings of this study, the following recommendations are put forward to the educational institutions, instructors and students, for a more constructive and effective online learning system. 


\subsection{Implications for Educational Institutions}

Creating a needs assessment survey among students, to pinpoint those with limited access to technological resources, especially among PU students. Adding courses that teach students the basic computer skills can be beneficial, since some students possessed insufficient computer and keyboarding skills. Offering English courses for students, to minimize the communication barriers and maximize students' oral and written skills during online classes, especially among PU students. Conducting trainings for instructors to better adapt them to online methods of learning as well as the creative and innovative techniques needed to increase students' motivation and engagement.

\subsection{Implications for Instructors}

Creating opportunities for meaningful interactions with students. Ensuring open communication channels among students and instructors. Improving the quality of the material provided to meet the students' expectations to online learning. Ensuring that the materials in online activities are engaging and motivating to the students. Implementing a suitable mode for content delivery, to facilitate group activities and enhance students' engagement. Using a blended learning approach, which includes supplementary on campus meetings besides the online classes, would be recommended whenever convenient, since students prefer face-to-face interactions with their instructors.

\subsection{Implications for Students}

Students have an important role in making the online learning experience successful. Therefore, from their side, they must ensure having a sound computer and the needed technological skills to effectively learn from the online lectures. Moreover, they need to be self-directed, self-regulated, have great discipline and time management skills to be able to regulate their own learning, and structure and plan their studies effectively.

\section{Limitations}

The results of this study may not be generalized to other populations since it solely focused on undergraduate students from Schools of Business in Egypt. Accordingly, it would be suggested to tackle other faculties and post graduate students as well. The scope of the study was limited to only one university of each type (PU, PR, and NA); future studies on more universities of each type is suggested. In addition to that, the data analysis was based on descriptive statistics only, applying further data analysis techniques is recommended, to test the relationships and correlations between the variables. It is also suggested to assess the students' learning achievements from online learning since the study only focused on the students' attitudes. Finally, since the survey concentrated on the students' attitudes towards online learning, the inclusion of the instructors' opinions in future studies can provide more insights and help in understating the challenges faced in online education. 


\section{Conclusion}

COVID-19 pandemic has forced all educational establishments worldwide to shift from the traditional methods of learning to online learning instead, which has resulted in an entirely different learning experience for students. Unfortunately, not all universities were ready for this sudden shift and radical restructuring of their educational process. In addition to that, there has been a dearth in literature, especially in the middle east, tackling the students' attitudes towards this sudden shift in the learning system.

This paper is the first to provide an analysis of the students' challenges faced, as well as their attitudes towards online learning in different universities in Egypt. A sample of 450 business undergraduate students from a national, public, and private universities in Egypt were surveyed. The main findings of this study revealed that the majority of students had reservations about online learning and that traditional learning (face-toface learning) was necessary for learning to occur (68\%).

Students' attitudes towards online learning were affected by five main challenges: technicalities, comfort with online communication, students learning motivation, students' self-discipline, regulation and time management, and the interaction of students with their colleagues and instructors. Overall findings revealed that there was a difference among students' attitudes among the three universities, where PR students generally held more favorable attitudes towards online learning, followed by NA, and then PU.

The findings of this study can serve as a foundation for future research. It also provides useful insights and implications that may aid universities in the formulation of strategies that may improve the online learning methods and enhance the students' overall experiences with online learning within the educational establishments.

\section{References}

[1] Cucinotta, D., \& Vanelli, M. (2020). WHO declares COVID-19 a pandemic. Acta biomedica: Atenei Parmensis, 91(1), 157-160.

[2] Adnan, M., \& Anwar, K. (2020). Online Learning amid the COVID-19 Pandemic: Students' Perspectives. Online Submission, 2(1), 45-51. https://doi.org/10.33902/jpsp.2020261309

[3] Almanthari, A., Maulina, S., \& Bruce, S. (2020). Secondary school mathematics teachers' views on E-learning implementation barriers during the COVID-19 pandemic: the case of Indonesia. Eurasia Journal of Mathematics, Science and Technology Education, 16(7), 1860. https://doi.org/10.29333/ejmste/8240

[4] Toquero, C. M. (2020). Challenges and opportunities for higher education amid the COVID19 pandemic: The Philippine context. Pedagogical Research, 5(4). https://doi.org/10. $29333 / \mathrm{pr} / 7947$

[5] Kaur, G. (2020). Digital Life: Boon or bane in teaching sector on COVID-19. CLIO an Annual Interdisciplinary Journal of History, 6(6), 416-427.

[6] Koch, L. F. (2014). The nursing educator's role in e-learning: A literature review. Nurse education today, 34(11), 1382-1387. https://doi.org/10.1016/j.nedt.2014.04.002

[7] Peterson, D. S. (2008). A meta-analytic study of adult self-directed learning and online nursing education: A review of research from 1995 to 2007 (Doctoral dissertation, Capella University). 
[8] Wu, Z. (2020). How a top Chinese university is responding to coronavirus.

[9] Spector, J. M., Merrill, M. D., van Merrienboer, J., Driscoll, M. P. (2008). Research on Educational Communications and Technology.

[10] Almusharraf, N., \& Khahro, S. (2020). Students Satisfaction with Online Learning Experiences during the COVID-19 Pandemic. International Journal of Emerging Technologies in Learning (iJET), 15(21), 246-267. https://doi.org/10.3991/ijet.v15i21.15647

[11] Crawford, J., Butler-Henderson, K., Rudolph, J., \& Glowatz, M. (2020). COVID-19: 20 countries' higher education intra-period digital pedagogy responses. Journal of Applied Teaching and Learning (JALT), 3(1). https://doi.org/10.37074/jalt.2020.3.1.7

[12] Basilaia, G., \& Kvavadze, D. (2020). Transition to online education in schools during a SARS-CoV-2 coronavirus (Covid-19) pandemic in Georgia. Pedagogical Research, 5(4), 19. https://doi.org/10.29333/pr/7937

[13] Zhong, R. (2020, March 17). The coronavirus exposes education's digital divide. Retrieved from The New York Times: https://www.nytimes.com/2020/03/17/technology/chinaschools-coronavirus.html

[14] Perifanou, M., Economides, A., \& Tzafilkou, K. (2021). Teachers' Digital Skills Readiness During COVID-19 Pandemic. International Journal of Emerging Technologies in Learning (iJET), 16(08), pp. 238-251. http://dx.doi.org/10.3991/ijet.v16i08.21011

[15] Ohene, J. B., \& Essuman, S. O. (2014). Challenges faced by distance education students of the University of Education, Winneba: Implications for strategic planning. Journal of Education and Training, 1(2), 156-176. https://doi.org/10.5296/jet.v1i2.5669

[16] Koi-Akrofi, G. Y., Owusu-Oware, E., \& Tanye, H. (2020) Challenges Of Distance, Blended, And Online Learning: A Literature-Based Approach. International Journal on Integrating Technology in Education (IJITE), 9(4). https://doi.org/10.5121/ijite.2020.9403

[17] Alexander, B., Ashford-Rowe, K., Barajas-Murph, N., Dobbin, G., Knott, J., McCormack, M., \& Weber, N. (2019). Horizon report 2019 higher education edition, 3-41.

[18] Johnson, L., Becker, S. A., Cummins, M., Estrada, V., Freeman, A., \& Hall, C. (2016). NMC horizon report: 2016 higher education edition. Austin: The New Media Consortium, 1-50

[19] Dumford, A. D., \& Miller, A. L. (2018). Online learning in higher education: Exploring advantages and disadvantages for engagement. Journal of Computing in Higher Education, 6, 1-14. https://doi.org/10.1007/s12528-018-9179-z

[20] Hillman, D. C. A., Willis, D. J., \& Gunawardena, C. N. (1994). Learner-interface interaction in distance education: An extension of contemporary models and strategies for practitioners. American Journal of Distance Education, 8(2), 30-42. https://doi.org/10.1080/0892364 $\underline{9409526853}$

[21] Moore, M. (1989). Three types of interaction; The American Journal of Distance Education.

[22] Moore, M. G., \& Kearsley, G. (1996). Distance education: A systems view. Belmont, CA: Wadsworth Publishing Company.

[23] Agustina, P. Z. R., \& Cheng, T. H. (2020). How Students' Perspectives about Online Learning Amid the COVID-19 Pandemic? Studies in Learning and Teaching, 1(3), 133-139. https://doi.org/10.46627/silet.v1i3.46

[24] Britt, R. (2006). Online education: A survey of faculty and students. Radiologic Technology, 77(3), 183190.

[25] Kim, S., Park, C., \& O"Rourke, J. (2017). Effectiveness of online simulation training: Measuring faculty knowledge, perceptions, and intention to adopt. Nurse Education Today, 51, 102-107. https://doi.org/10.1016/j.nedt.2016.12.022

[26] Zhou, M. M. (2016). Chinese university students' acceptance of MOOCs: A self-determination perspective. Computer \& Education, 92-93, 194-203. https://doi.org/10.1016/j. compedu.2015.10.012 
[27] Pace, C., Pettit, S. K., \& Barker, K. S. (2020). Best practices in middle level quaranteaching: Strategies, tips and resources amidst COVID-19. Journal of the Georgia Association for Middle Level Education, 31(1), 2. https://doi.org/10.20429/becoming.2020.310102

[28] Huang, R.H., Liu, D.J., Tlili, A., Yang, J.F., Wang, H.H., et al. (2020). Handbook on facilitating flexible learning during educational disruption: The Chinese experience in maintaining undisrupted learning in COVID-19 outbreak. Smart Learning Institute of Beijing Normal University.

[29] Powell, A., Roberts, V., \& Patrick, S. (2015). Using online learning for credit recovery: Getting back on track to graduation. International Association for K-12 Online Learning.

[30] Barr, B. A., \& Miller, S. F. (2013). Higher Education: The Online Teaching and Learning Experience. Online Submission.

[31] Bernard, R. M., Brauer, A., Abrami, P. C., \& Surkes, M. (2004). The development of a questionnaire for predicting online learning achievement. Distance education, 25(1), 31-47. https://doi.org/10.1080/0158791042000212440

[32] Nora, A., \& Snyder, B. P. (2008). Technology and higher education: The impact of e-learning approaches on student academic achievement, perceptions and persistence. Journal of College Student Retention: Research, Theory \& Practice, 10(1), 3-19. https://doi.org/10. 2190/cs.10.1.b

[33] Patterson, B., \& McFadden, C. (2009). Attrition in online and campus degree programs. Online Journal of Distance Learning Administration, 12(2).

[34] Radha, R., Mahalakshmi, K., Kumar, V. S., \& Saravanakumar, A. R. (2020). E-Learning during lockdown of Covid-19 pandemic: A global perspective. International journal of control and automation, 13(4), 1088-1099.

[35] Alasmari, T. (2021). Learning in the COVID-19 Era: Higher Education Students and Faculty's Experience with Emergency Distance Education. International Journal of Emerging Technologies in Learning, 16(9). https://doi.org/10.3991/ijet.v16i09.20711

[36] Obeidat, M. M. (2020). Undergraduate Students' Perspective About Online Learning: A Case Study of Hashemite University Students in Jordan. European Journal of Molecular \& Clinical Medicine, 7(8), 4054-4071.

[37] Ghenghesh, P., Croxford, L., Nagaty, K., \& Abdelmageed, S. (2018). Students and Teachers Attitudes and Satisfaction toward E-Learning: A Case Study in Egypt. The Journal of Middle East and North Africa Sciences, 10(5637), 1-17. https://doi.org/10.12816/0044059

[38] Tamim, R. M., Bernard, R. M., Borokhovski, E., Abrami, P. C., \& Schmid, R. F. (2011). What forty years of research says about the impact of technology on learning: A secondorder meta-analysis and validation study. Review of Educational research, 81(1), 4-28. https://doi.org/10.3102/0034654310393361

[39] Baticulon, R. E., Alberto, N. R. I., Baron, M. B. C., Mabulay, R. E. C., Rizada, L. G. T., Sy, J. J., \& Reyes, J. C. B. (2020). Barriers to online learning in the time of COVID-19: A national survey of medical students in the Philippines. medRxiv. https://doi.org/10.1101/ $\underline{2020.07 .16 .20155747}$

[40] Muhammad, N., \& Srinivasan, S. (2021). Online Education During a Pandemic-Adaptation and Impact on Student Learning. International Journal of Engineering Pedagogy, 11(3).

[41] Musingafi, M. C., Mapuranga, B., Chiwanza, K., \& Zebron, S. (2015). Challenges for open and distance learning (ODL) students: Experiences from students of the Zimbabwe Open University. Journal of Education and Practice, 6(18), 59-66.

[42] Muilenburg, L. Y., \& Berge, Z. L. (2005). Student barriers to online learning: A factor analytic study. Distance education, 26(1), 29-48. https://doi.org/10.1080/01587910500081269 
[43] Farrell, O., \& Brunton, J. (2020). A balancing act: a window into online student engagement experiences. International Journal of Educational Technology in Higher Education, 17, 119. https://doi.org/10.1186/s41239-020-00199-x

[44] Zhu, Y., Zhang, J. H., Au, W., \& Yates, G. (2020). University students' online learning attitudes and continuous intention to undertake online courses: a self-regulated learning perspective. Educational Technology Research and Development, 1-35. https://doi.org/10.1007 /s11423-020-09753-w

[45] Basha, I., Hussein, A., \& Maklad, N. (2021). Distance Learning Applicability in Egyptian Construction Engineering Education. International Journal of Emerging Technologies in Learning (iJET), 16(3), 220-234. https://doi.org/10.3991/ijet.v16i03.18019

[46] The Board of Trustees of the University of Illinois. Strengths and weaknesses of online learning. ION professional eLearning programs. University of Illinois Springfield, 2020.

[47] Amir, L. R., Tanti, I., Maharani, D. A., Wimardhani, Y. S., Julia, V., Sulijaya, B., \& Puspitawati, R. (2020). Student perspective of classroom and distance learning during COVID-19 pandemic in the undergraduate dental study program Universitas Indonesia. BMC medical education, 20(1), 1-8. https://doi.org/10.21203/rs.3.rs-42334/v2

[48] Loeb, S. (2020). How effective is online learning? What the research does and doesn't tell us. Education Week, 1

[49] Sit, J. W., Chung, J. W., Chow, M. C., \& Wong, T. K. (2005). Experiences of online learning: students' perspective. Nurse education today, 25(2), 140-147. https://doi.org/10.1016/j. nedt.2004.11.004

[50] Jacques, S., Ouahabi, A., \& Lequeu, T. (2020). Remote Knowledge Acquisition and Assessment During the COVID-19 Pandemic. International Journal of Engineering Pedagogy (iJEP), 10. https://doi.org/10.3991/ijep.v10i6.16205

[51] Firmansyah, R., Putri, D. M., Galih, M., Wicaksono, S., Putri, S. F., Widianto, A. A., \& Palil, M. R. (2021). Educational Transformation: An Evaluation of Online Learning Due to COVID-19. International Journal of Emerging Technologies in Learning, 16(7). https://doi. org/10.3991/ijet.v16i07.21201

[52] Liu, Y. (2021). Blended Learning of Management Courses Based on Learning Behaviour Analysis. International Journal of Emerging Technologies in Learning, 16(9).

\section{Authors}

Hebatalla Kaoud is a lecturer of Innovation Management and Entrepreneurship at the School of Business \& Finance, Newgiza University (NGU). Hebatalla graduated with a PhD in Management Sciences from Nantes University - France, in 2018. Hebatalla participated in many international research and business conferences in countries including France, Germany, Spain, Morocco, Tunis. Hebatalla has 7 years of experience in Innovation Management in France and Egypt. Moreover, she is an executive board member at Egylière company. Having both academic and professional expertise in innovative project management and entrepreneurship, Dr. Hebatalla Kaoud guided students in applying knowledge learned to real business situations.

Dina El-Shihy is a Lecturer of Marketing (specialized in Digital Marketing and Consumer Behavior on Digital Platforms) and the Academic Coordinator of the BBM Program in NGU. Dr. Dina has more than 10 years of experience in the academic field and has attended several workshops and undergone various internships in the banking sector and at the UNESCO. 
Mostafa Yousri is an Associate Professor of Mathematics and Risk Management. He holds a diploma in business from Redbridge College, London, as well as a Ph.D. in Enterprise Risk Management from Cairo University. Dr. Mostafa teaches Business Mathematics, Statistics, and Risk Management at NGU, and FCES and GSUCU joint program, Cairo University.

Article submitted 2021-06-29. Resubmitted 2021-08-05. Final acceptance 2021-08-06. Final version published as submitted by the authors. 